\title{
Deteminan Kejadian Stunting Pada Anak Usia 24-59 Bulan Di Wilayah Puskesmas Saigon Kecamatan Pontianak Timur
}

\section{Determination Stunting Of Children 24-59 Months In The Puskesmas Saigon, West Kalimantan}

\author{
Lydia Febri Kurniatin,S.ST.,M.Keb ${ }^{1 *}$ Lepita,S.ST.,M.Keb ${ }^{2}$ \\ 1. Jurusan Kebidanan, Poltekkes Kemenkes Pontianak, Indonesia \\ 2. Jurusan Kebidanan, Poltekkes Kemenkes Pontianak, Indonesia \\ * Email korespondensi: Lydia.febriy@gmail.com
}

\begin{abstract}
Abstrak
Latar Belakang: Kejadian balita stunting merupakan masalah gizi yang dialami oleh balita di dunia saat ini. Pada tahun 2017, 22,2\% atau sekitar 150,8 juta balita di dunia mengalami stunting. Kelurahan Saigon merupakan salah satu kelurahan yang berada di Kecamatan Pontianak Timur Provinsi Kalimantan Barat dengan angka kejadian stunting tertinggi yaitu sebanyak 62 balita (20,7\%).

Tujuan: mengidentifikasi determinan kejadian stunting pada balita usia 24-59 bulan di wilayah Puskesmas Saigon Kecamatan Pontianak Timur Provinsi Kalimantan Barat tahun 2019

Metode: Jenis penelitian observasional analitik dengan desain case control. Jumlah sampel yaitu 64 balita usia 24-59 bulan. Menggunakan teknik samplingpurposive. Uji statistik yang digunakan adalah chi squaredan regresi logistik

Hasil :Terdapat 5 variabel yang memiliki hubungan bermakna diantaranya BBLR ( $p$ value $=0,008$ dan OR $=2,89$ ), riwayat KEK ( $p$ value $=0,001)$, ASI eksklusif ( $p$ value $=0,001$ dan $\mathrm{OR}=6,67)$, MP ASI ( $p$ value $=0,001$ dan OR $=120$ ), keterpaparan informasi tentang 1000 HPK pada ibu ( $p$ value $=$ $0,001$ dan OR $=2,4)$. BBLR menunjukkan peluang paling besar untuk memengaruhi kejadaian stunting.
\end{abstract}

Kesimpulan : BBLR, riwayat KEK, ASI eksklusif, MP ASI dan keterpaparan informasi tentang 1000 HPK pada ibu memiliki hubungan bermakna dengan stunting.

Kata kunci: Determinan, stunting, Kalimantan barat

\section{Abstract}

Background: Saigon Village is one of the villages in the East Pontianak District of West Kalimantan Province with theincidence of stunting highest, which is 62 toddlers (20.7\%).

Objective: toidentify the determinants of stunting in toddlers aged 24-59 months in the area of Puskesmas Saigon, East Pontianak District, West Kalimantan Province in 2019

Method: This study is observational analytic study with case control design. The number of samples is 64 toddlers aged 24-59 months. Usingsampling technique purposive. The statistical test used is chi square and logistic regression

Results:There are 5 variables that have a significant relationship including $L B W$ ( $p$ value $=$ 0.008 and $O R=2.89$ ), history of SEZ ( $p$ value $=0,001)$, exclusive breastfeeding ( $p$ value $=$ 0.001 and $O R=6.67), M P$ ASI ( $p$ value $=0,001$ and $O R=120)$, information about 1000 HPK in mothers ( $p$ value $=0,001$ and $O R=2,4$ ). LBW shows the greatest opportunity to influence the existence of stunting.

Conclusion: LBW, KEK history, exclusive breastfeeding, complementary feeding and exposure information on 1000 HPK in the mother has a significant relationship with stunting.

Keywords: Determinant, stunting, West Kalimantan 


\section{PENDAHULUAN}

Kejadian balita pendek atau biasa disebut dengan stunting merupakan salah satu masalah gizi yang dialami oleh balita di dunia saat ini. Pada tahun 2017, 22,2\% atau sekitar 150,8 juta balita di dunia mengalami stunting. Pada tahun 2017 , lebih dari setengah balita stunting di dunia berasal dari Asia (55\%) sedangkan lebih dari sepertiganya (39\%) tinggal di Afrika. Dari 83,6 juta balita stunting di Asia, proporsi terbanyak berasal dari Asia Selatan $(58,7 \%)$ dan proporsi paling sedikit di Asia Tengah $(0,9 \%)^{1}$. Angka kejadian gizi Balita sangat pendek dan pendek di Kalimantan barat juga cukup tinggi. Kalimantan barat menempati urutan ke-8 di tahun 2019 yaitu sebesar 33,5\% ${ }^{1}$

Stunting adalah kondisi gagal tumbuh pada anak balita (bayi di bawah lima tahun) akibat dari kekurangan gizi kronis sehingga anak terlalu pendek untuk usianya. Kekurangan gizi terjadi sejak bayi dalam kandungan dan pada masa awal setelah bayi lahir akan tetapi kondisi stunting baru nampak setelah bayi berusia 2 tahun. Balita stunting termasuk masalah gizi kronik yang disebabkan oleh banyak faktor seperti kondisi sosial ekonomi, gizi ibu saat hamil, kesakitan pada bayi, dan kurangnya asupan gizi pada bayi. Selain itu, praktik pengasuhan yang kurang efektif dan terbatasnya akses pelayanan kesehatan selama 1000 Hari Pertama Kehidupan (HPK) juga mempengaruhi risiko stunting.Balita stunting di masa yang akan datang akan mengalami kesulitan dalam mencapai perkembangan fisik dan kognitif yang optimal $^{2}$

Dalam jangka pendek, dampak stunting dapat meningkatkan kejadian kesakitan dan kematian, perkembangan kognitif, motorik dan verbal yang tidak optimal, kapasitas belajar dan performa yang kurang baik serta peningkatan biaya kesehatan. Anak-anak yang menderita stunting akan tumbuh dengan postur tubuh yang tidak optimal, berisiko obesitas, hipertensi, diabetes hingga kanker. Selain itu juga menurunkan kesehatan reproduksi, serta menurunkan produktivitas dan kapasitas kerja. Dampak tersebut juga tentunya akan menjadi beban negara dan meningkatkan potensi kerugian ekonomi yang sangat besar Untuk mencegah hal tersebut, pemerintah mencanangkan program intervensi pencegahan stunting terintegrasi yang melibatkan lintas kementerian dan lembaga. Pada tahun 2019, ditetapkan 100 kabupaten di 34 provinsi sebagai lokasi prioritas penurunan stunting. Jumlah ini akan bertambah sebanyak 60 kabupaten pada tahun berikutnya. Dengan adanya kerjasama lintas sektor ini diharapkan dapat menekan angka stunting di Indonesia sehingga dapat tercapai target Sustainable Development Goals (SDGs) pada tahun 2025 yaitu penurunan angka stunting hingga 40\%. ${ }^{3}$

Angka kejadian stunting di Kota Pontianak juga cukup tinggi. Data Dinas Kesehatan Kota Pontianak tahun 2018 mengggambarkan dari 8800 balita yang ditimbang, sebanyak $1359(15,8 \%)$ balita mengalamipendekdan 540 (6,3\%) balita didiagnosis sangat pendek. Dari 6 kecamatan yang ada di Kota Pontianak, Kecamatan Pontianak Timur merupakan kecamatan dengan angka stunting tertinggi. Dari 2100 balita yang ditimbang, 437 (20,8\%) balita mengalami pendek dan $183(8,7 \%)$ balita didiagnosis sangat pendek. Kelurahan Saigon merupakan salah satu dari 3 kelurahan yang berada di wilayah Kecamatan Pontianak Timur dengan angka kejadian stunting tertinggi yaitu sebanyak $62(20,7 \%)$ balita $^{4}$

Pemerintah Kota Pontianak telah pro aktif dalam menekan kejadian stunting diantaranya dengan program screening balita pendek, pemberian makanan tambahan (PMT), promosi kesehatan terkait pencegahan stunting pada ibu balita serta pendirian Therapy Feeding Centre (TFC)khususnya di Puskesmas Saigon ${ }^{5}$

Berdasarkan permasalahan tersebut dan masih tingginya prevalensi stunting pada anak di bawah tiga tahun, perlu diteliti lebih lanjut faktor risiko apa saja yang menyebabkan stunting di Wilayah Puskesmas Saigon Kecamatan Pontianak Timur. Tujuan penelitian adalah menganalisis faktor risiko terkait faktor anak, ibu dan lingkungan terhadap kejadian stunting 
di Wilayah Puskesmas Saigon Kecamatan Pontianak Timur agar nantinya dapat dikembangkan model untuk pengendalian faktor risiko stunting tersebut.

\section{METODE}

Jenis penelitian survey analitik dengan rancangan case control. Penelitian ini dilaksanakan di wilayah Puskesmas Saigon Kecamatan Pontianak Timur mulai bulan Maret hingga Oktober 2019. Populasi pada penelitian ini adalah seluruh balita usia 24-59 bulan di wilayah Puskesmas Saigon Kecamatan Pontianak Timur. Sampel dalam penelitian ini adalah seluruh kasus stunting usia 24-59 bulan dan sebagai kontrol diambil sebesar kasus dengan perbandingan 1:1. Jumlah kasus stunting di wilayah Puskesmas Saigon Kecamatan Pontianak Timur adalah 34 kasus. Dilakukan matching usia dan jenis kelamin pada kelompok kontrol. Dalam penelitian ini, pengambilan sampel untuk kelompok control dengan menggunakan non random sampling dengan teknik purposive sampling. Kriteria kasus dalam penelitian ini adalah 1) balita usia 24-59 bulan dengan stunting yang dinilai dengan indeks Z-score TB/U < -2 SD atau tercatat di buku KMS/KIA dan bersedia menjadi sampel. Untuk kasus kontrol adalah balita usia 24-59 bulan dengan indeks Z-score TB/U -2 SD sampai + 2SD (tidak mengalami stunting) atau tercatat di buku KMS/KIA dan bersedia menjadi sampel.

Sebelum penelitian dilakukan diajukan permohonan rekomendasi kaji etik kepada Komisi Etik Penelitian Kesehatan Politeknik Kesehatan Pontianak dan telah disetujui dengan surat No.190/KEPK-PK.PKP/V/2019.

\section{HASIL}

Analisis univariat berfungsi mendeskripsikan distribusi frekuensi karakteristik responden terhadap kaitannya dengan kejadian stunting. Karakteristik yang peneliti kaji adalah pendidikan, pekerjaan dan usia ibu saat hamil. Hasil analisis tersebut tergambar pada tabel 1 berikut ini.

\section{Tabel 1.Analisis Hubungan Karakteristik Responden dengan kejadian Stunting}

Tabel 1 mendeskripsikan sebagian dari ibu yang memiliki balita stunting 18 orang

\begin{tabular}{|c|c|c|c|c|c|c|c|c|}
\hline \multirow[b]{2}{*}{ Variabel } & \multicolumn{4}{|c|}{ Kejadian Stunting } & \multirow[b]{2}{*}{ Total } & \multirow[b]{2}{*}{$\%$} & \multirow{2}{*}{$\begin{array}{c}P- \\
\text { Value }\end{array}$} & \multirow[b]{2}{*}{$O R$} \\
\hline & Stunting & $\%$ & $\begin{array}{c}\text { Tidak } \\
\text { Stunting }\end{array}$ & $\%$ & & & & \\
\hline \multicolumn{9}{|l|}{ Pendidikan Ibu } \\
\hline Dasar & 18 & 52 & 7 & 20,6 & 25 & 36,8 & \multirow[t]{2}{*}{0,021} & \\
\hline Menengah & 13 & 38,2 & 21 & 61,8 & 34 & 50 & & \\
\hline Tinggi & 3 & 8,8 & 6 & 17,6 & 9 & 13,2 & & \\
\hline \multicolumn{9}{|l|}{ Pekerjaan Ibu } \\
\hline Bekerja & 5 & 14,7 & 5 & 14,7 & 10 & 14,7 & \multirow[t]{2}{*}{1} & \multirow[t]{2}{*}{1} \\
\hline Tidak Bekerja & 28 & 85,3 & 29 & 85,3 & 58 & 85,3 & & \\
\hline \multicolumn{9}{|c|}{ Usia Ibu Saat Hamil } \\
\hline Berisiko & 4 & 11,8 & 2 & 5,9 & 6 & 8,8 & \multirow[t]{2}{*}{0,69} & \multirow[t]{2}{*}{2,1} \\
\hline Tidak Berisiko & 30 & 88,2 & 32 & 94,1 & 62 & 91,2 & & \\
\hline
\end{tabular}

(52\%) berpendidikan menengah, hampir seluruh ibu tersebut adalah ibu rumah tangga $(85,3 \%)$, dan, hampir seluruh ibu tersebut hamil pada usia tidak berisiko $30(88,2 \%)$. 
Analisis selanjutnya yang peneliti gunakan adalah dengan analisis bivariate yaitu dengan menggunakan analisis chisquare. Hasil analisis tersebut terdapat pada tabel 2 di bawah ini.

Tabel 2.Analisis HubunganBBLR, Jarak Kehamilan, Tablet Fe, Riwayat ANC dan KEK, Riwayat ASI Eksklusif, MP ASI, Imunisasi, Keterpaparan Informasi 1000 HPK dengan Kejadian Stunting

\begin{tabular}{|c|c|c|c|c|c|c|c|c|}
\hline \multirow{2}{*}{ Variabel } & \multicolumn{4}{|c|}{ Kejadian Stunting } & \multirow{2}{*}{ Total } & \multirow{2}{*}{$\%$} & \multirow{2}{*}{ P-Value } & \multirow{2}{*}{$O R$} \\
\hline & Stunting & $\%$ & Tidak Stunting & $\%$ & & & & \\
\hline \multicolumn{9}{|l|}{ Berat Lahir } \\
\hline BBLR & 8 & 23,5 & 0 & 0 & 8 & 11,8 & \multirow[t]{2}{*}{0,008} & \multirow[t]{2}{*}{2,89} \\
\hline Tidak BBLR & 26 & 76,5 & 34 & 100 & 60 & 88,2 & & \\
\hline \multicolumn{9}{|l|}{ Jarak Kehamilan } \\
\hline Berisiko & 5 & 14,7 & 13 & 38,2 & 18 & 26,5 & \multirow[t]{2}{*}{0,054} & \multirow[t]{2}{*}{0,279} \\
\hline Tidak Berisiko & 29 & 85,3 & 21 & 61,8 & 50 & 73,5 & & \\
\hline \multicolumn{9}{|l|}{ Tablet Fe } \\
\hline Rutin & 21 & 61,8 & 28 & 84,2 & 49 & 72,1 & \multirow[t]{2}{*}{0,1} & \multirow[t]{2}{*}{2,89} \\
\hline Tidak Rutin & 13 & 38,2 & 6 & 17,6 & 19 & 27,9 & & \\
\hline \multicolumn{2}{|l|}{ Riwayat KEK } & & & & & & \multirow{3}{*}{0,001} & \multirow{3}{*}{0,094} \\
\hline KEK & 12 & 35,3 & 29 & 85,3 & 41 & 60,3 & & \\
\hline Tidak KEK & 22 & 64,7 & 5 & 14,7 & 27 & 39,7 & & \\
\hline \multicolumn{9}{|l|}{ Riwayat ANC } \\
\hline Sesuai Standar & 31 & 91,2 & 34 & 100 & 65 & 95,6 & \multirow[t]{2}{*}{0,2} & \multirow[t]{2}{*}{1} \\
\hline Tidak Sesuai Standar & 3 & 8,8 & 0 & 0 & 3 & 4,4 & & \\
\hline \multicolumn{9}{|l|}{ Riwayat IMD } \\
\hline IMD & 24 & 70,6 & 28 & 82,4 & 52 & 76,5 & \multirow[t]{2}{*}{0,39} & \multirow[t]{2}{*}{1,9} \\
\hline Tidak IMD & 10 & 29,4 & 6 & 17,6 & 16 & 23,5 & & \\
\hline \multicolumn{9}{|l|}{ Riwayat ASI } \\
\hline ASI eksklusif & 9 & 26,5 & 24 & 70,6 & 33 & 48,5 & \multirow{2}{*}{0,001} & \multirow[t]{2}{*}{6,67} \\
\hline Tidak ASI eksklusif & 25 & 73,5 & 10 & 29,4 & 35 & 51,5 & & \\
\hline \multicolumn{9}{|l|}{ Riwayat MP ASI } \\
\hline MP ASI sesuai & 4 & 11,8 & 32 & 94,1 & 36 & 52,9 & \multirow[t]{2}{*}{0,001} & 120 \\
\hline MP ASI tidak sesuai & 30 & 88,2 & 2 & 5,91 & 32 & 47,1 & & \\
\hline Riwayat Imunisasi & & & & & & & & \\
\hline Imunisasi Lengkap & 24 & 70,6 & 29 & 85,3 & 53 & 77,9 & 0,2 & 2,4 \\
\hline Tidak Imunisasi Lengkap & 10 & 29,4 & 5 & 14,7 & 15 & 22,1 & & \\
\hline Informasi 1000 HPK & & & & & & & & \\
\hline Pernah & 17 & 50 & 1 & 2,9 & 18 & 26,5 & 0,001 & 2,4 \\
\hline Tidak Pernah & 17 & 50 & 33 & 97,1 & 50 & 73,5 & & \\
\hline
\end{tabular}

Hasil analisis bivariate pada tabel 2 di atas menggambarkan pada kelompok ibu yang memiliki balita stunting, sangat sedikit responden yang memiliki riwayat persalinan dengan BBLR $(23,5 \%)$, sangat sedikit responden yang memiliki riwayat jarak kehamilan kurang dari 2 tahun $(14,7 \%)$, hanya sebagian kecil responden yang memiliki riwayat tidak rutin dalam mengkonsumsi tablet Fe selama kehamilan $(38,2 \%)$, sangat sedikit responden yang memiliki riwayat mendapatkan pelayanan ANC tidak seusai 10 standar $(8,8 \%)$, sebagian besar responden memiliki riwayat tidak memberikan ASI secara eksklusif $(73,5 \%)$, hamper seluruh responden memiliki riwayat pemberian MP ASI tidak sesuai standar $(88,2 \%)$, sangat sedikit responden yang memiliki riwayatsangat sedikit responden yang memiliki riwayat tidak mendapatkan imunisasi secara lebgkap $(29,4 \%)$, sebagian dari responden memiliki riwayat tidak mendapatkan informasi 1000 HPK (50\%).

Hasil analisis juga menggambarkan riwayat persalinan dengan BBLR, riwayat kehamilan dengan KEK,riwayat pemberian ASI eksklusif, riwayat pemberian MP ASI serta 
keterpaparan informasi 1000 HPK memiliki hasil uji chiquare dengan p value $<0,05$ sehingga memiliki hubungan yang bermakna dengan kejadian balita stunting.

Analisis multivariate bertujuan untuk mengetahui variable apa yang sangat memengaruhi terjadinya stunting, berdasarkan pemodelan dan melihat kekuatan diantara variable-variabel tersebut, secara parsial memengaruhi variable dependent.

Tabel 3.Pengaruh BBLR, MPAsi, dan 1000 HPK Terhadap Kejadian Stunting

\begin{tabular}{ccccc}
\hline & Variabel & B & Sig & Exp $(\beta)$ \\
\hline Step $8^{\mathrm{a}}$ & BBLR(1) & -22.207 & .998 & .000 \\
\cline { 2 - 5 } & MPAsi(1) & -5.240 & .000 & .005 \\
\cline { 2 - 5 } & HPK(1) & 3.620 & .026 & 37.347 \\
\cline { 2 - 5 } & Constant & 23.948 & .998 & 25146706460.273 \\
\hline
\end{tabular}

\section{PEMBAHASAN}

Tabel 1 di atas menggambarkan hasil analisis chi square hubungan karakteristik responden dengan kejadian stunting. Uji statistik pada viariabel pendidikan ibu diperoleh $p$ value $=0.021$ sehingga dapat disimpulkan bahwa terdapat hubungan yang bermakna antara pendidikan ibu dengan kejadian stunting. Hasil analisis variable pekerjaan menunjukan nilai $p$-value $=1$ sehingga disimpulkan bahwa tidak terdapat hubungan yang bermakna antara pekerjaan ibu dengan kejadian stunting. Hasil analisis variable usia ibu saat hamil menunjukan nilai $p$-value $=0,69$ sehingga disimpulkan bahwa tidak terdapat hubungan yang bermakna antara usia ibu saat hamil dengan kejadian stunting.

Stunting merupakan hasil penilaian TB/U yang merefleksikan status gizi masa lalu,dalam hal ini usia 24-59 bulan. Dalam rentang usia tersebut, ibu berperan penting dalam pola pengasuhan anak, mulai dari pemberian ASI selama 6 bulan, penyediaan bahan yang berkualitas untuk MP ASI, Imunisasi dasar lengkap, hingga pemantauan tumbuh dan kembang balitanya. Pola dan kualitas pengasuhan, juga dipengaruhi oleh banyak faktor, diantaranya adalah tingkat pendidikan ibu. Penelitian lain menjelaskan pendidikan dasar 1.28 kali menyebabkan bayi menjadi stunting .

Hasil analisis variable pekerjaan menunjukan nilai $p$-value $=1$ sehingga disimpulkan bahwa tidak terdapat hubungan yang bermakna antara pekerjaan ibu dengan kejadian stunting. Dalam penelitian ini 85,3\% ibu tidak bekerja, dengan distibusi 5 orang ibu bekerja dan 28 orang ibu tidak bekerja memiliki balita stunting.

Analisis selanjutnya yang peneliti gunakan adalah dengan analisis bivariate yaitu dengan menggunakan analisis chisquare. Untuk variable BBLR, berdasarkan tabel 2 di atas dapat dilihat bahwa uji statistik pada viariabel berat lahir diperoleh $p$-value $=0.008$ sehingga dapat disimpulkan bahwa terdapat hubungan yang bermakna antara BBLR dengan kejadian stunting. Hasil analisis lain menunjukan nilai Odd Ratio sebesar 2,89 sehingga disimpulkan bahwa balita dengan riwayat BBLR akan memiliki peluang sebesar 2,89 kali untuk mengalami stunting.

Berat Badan Lahir Rendah (BBLR) didefenisikan oleh WHO sebagai berat lahir $<2500$ gram.Berat lahir ditentukan oleh dua proses yaitu lama kehamilan dan laju pertumbuhan janin. Bayi baru lahir dapat memiliki berat lahir <2500 gr karena lahir dini (kelahiran premature) atau lahir kecil untuk usia kehamilan. Berat lahir juga indikator potensial untuk pertumbuhan bayi, respon terhadap rangsangan, lingkungan, dan untuk bayi bertahanhidup. Berat lahir memiliki dampak yang besar terhadap pertumbuhan anak, perkembangan anak dan tinggi badan pada saat dewasa. Bayi lahir dengan berat lahir rendah akan berisiko tinggi pada 
morbiditas, kematian, penyakit infeksi, kekurangan berat badan dan stunting diawal periode neonatal sampai masa kanak-kanak ${ }^{1}$

Hasil penelitian Nshimyiryo, et al (2019) juga menjelaskan bahwa BBLR merupakan salah satu faktor risiko yang dapat menyebabkan stunting pada balita. BBLR berpeluang 2 kali menjadi stunting dibandingkan bayi yang lahir dengan berat dalam range normal (> 2500 gram ${ }^{6}$

Untuk variabel riwayat KEK selama kehamilan berdasarkan tabel 4.2 di atas dapat dilihat bahwa $p$-value $=0.000$ sehingga dapat disimpulkan bahwa terdapat hubungan yang bermakna antara riwayat KEK selama kehamilan dengan kejadian stunting.

Kondisi kesehatan dan status gizi ibu saat hamil dapat mempengaruhi pertumbuhan dan perkembangan janin. Ibu yang mengalami kekurangan energi kronis atau anemia selama kehamilan akan melahirkan bayi dengan berat badan lahir rendah (BBLR).BBLR banyak dihubungkan dengan risiko tinggibadan yang kurang atau stunting.Oleh karena itu diperlukannya upaya pencegahan dengan menetapkan dan/atau memperkuat kebijakan untuk meningkatkan gizi WUS ${ }^{1}$

Untuk variabel riwayat ASI eksklusif berdasarkan tabel di atas dapat dilihat bahwa $p$ value $=0.001$ sehingga dapat disimpulkan bahwa terdapat hubungan yang bermakna antara riwayat pemberian ASI ekslusif dengan kejadian stunting. Hasil analisis lain menunjukan nilai Odd Ratio sebesar 6,67 sehingga disimpulkan bahwa balita yang tidak mendapatkan ASI eksklusif akan memiliki peluang sebesar 6,67 kali untuk mengalami stunting.

ASI merupakan makanan alami, berenergi tinggi, mudah dicerna dan mengandung komposisi nutrisi yang seimbang serta sempurna untuk tumbuh kembang bayi yang tersedia setiap saat, dan bebas dari kontaminasi ${ }^{7}$

ASI mengandung beranekaragam zat gizi yang dapat memenuhi kebutuhan bayi dalam pertumbuhan dan perkembangannya. ASI juga mengandung berbagai perlindungan spesifik dan non spesifik yang dapat melindungi bayi dari berbagai infeksi seperti Ig A, Ig G, Ig M, Lisosin dan laktoferin yang tidak ditemuka dalam susu sapi ${ }^{8}$

Memberikan ASI secara eksklusif akan memberikan kekebalan kepada balita sehingga tidak mudah terserang berbagai infeksi. Nutrisi yang disediakan sangat lengkap dan sesuai dengan kebutuhan balita. Hal tersebut tentunya akan membuat pertumbuhan dan perkembangan balita menjadi maksimal dan tidak akan mengalami stunting. Hasil studi berbasis komunitas di Nepal pada 118 kasus balita stunting dan 236 kontrol mendapatkan hasil yang tidak jauh berbeda. Balita yang tidak mendapatkan asi eksklusif selama 6 bulan berisiko akan mengalami stunting 6,9 kali dibandingkan balita yang mendapatkan ASI ekslusif ${ }^{9}$. Hal serupa juga ditemukan pada penelitian observasional analitik pada 99 balita di Nusa Tenggara Barat. Faktor yang paling mempengaruhi kejadian stunting adalah tidak memberikan ASI secara eksklusif ${ }^{10}$

Untuk variabel riwayat MP ASI berdasarkan tabel 2 dapat dilihat bahwa $p$-value = 0.000 sehingga dapat disimpulkan bahwa terdapat hubungan yang bermakna antara riwayat pemberian MP ASI gizi seimbang dengan kejadian stunting. Hasil analisis lain menunjukan nilai Odd Ratio sebesar 120 sehingga disimpulkan bahwa balita yang tidak mendapatkan MP ASI dengan gizi seimbang akan memiliki peluang sebesar 120 kali untuk mengalami stunting.

Praktik pemberian MP ASI yang kurang baik masih banyak ditemukan di masyarakat di antaranya diberikan saat bayi berusia kurang dari 6 bulan dengan frekuensi dan kualitas yang kurang memadai. MP ASI seharusnya diberikan saat bayi berusia 6 bulan dengan tambahan energi kurang lebih $200 \mathrm{kkal}$ per hari. MP ASI yang diberikan harus adekuat yaitu memenuhi kebutuhan energi, protein dan mikronutrien.MP ASI juga diberikan secara responsif ketika bayi menunjukkan tanda sudah siap untuk makan. MP ASI di awali dengan memberikan makanan halus/ saring kemudian meningkat pada frekuensi dan konsistensi/tekstur menjadi 
makanan keluarga di usia 12 bulan. Selain itu, praktik pemberian MP ASI juga harus higienis, diantaranya dengan memastikan kebersihan tangan dengan mencuci tangan dan peralatan yang digunakan ${ }^{11}$

Untuk variabel riwayat imunisasi dasar lengkap berdasarkan tabel di atas dapat dilihat bahwa $p$-value $=0,2$ sehingga dapat disimpulkan bahwa tidak terdapat hubungan yang bermakna antara riwayat imunisasi dasar lengkap dengan kejadian stunting.

Untuk variabel riwayat keterpaparan informasi tentang $1000 \mathrm{HPK}$, berdasarkan tabel di atas dapat dilihat bahwa p-value $=0.000$ sehingga dapat disimpulkan bahwa terdapat hubungan yang bermakna antara riwayat keterpaparan informasi tentang 1000 HPK dengan kejadian stunting. Hasil analisis lain menunjukan nilai Odd Ratio sebesar 2,4 sehingga disimpulkan bahwa ibu yang tidak mendapatkan informasi tentang $1000 \mathrm{HPK}$ akan memiliki peluang sebesar 2,4 kali untukmengalami stunting.

Periode 1000 hari pertama kehidupan terdiri dari 270 hari selamakehamilan dan 730 hari dari kelahiran sampai usia 2 tahun. Dengandemikian, 1000 hari pertama kehidupan terjadi pada saat ibu hamil danmenyusui hingga usia anak 23 bulan.Periode ini disebut pula sebagai window of opportunities atau golden periode (periode emas).Periode 1000 hari pertama kehidupan merupakan periode kritisdalam kehidupan manusia dan memberikan dampak jangka panjangterhadap kesehatan dan fungsinya. Dampak yang ditimbulkan diantaranya adalah malnutrition pada periode ini bersifat permanen dan berjangka panjang ${ }^{12}$

Dalam penelitian yang telah peneliti lakukan, tidak ditemukan hubungan yang bermakna antara riwayat jarak kelahiran, keteraturan mengkonsumsi tablet $\mathrm{Fe}$, melakukan pemeriksaan kehamilan sesuai standar, dan pelaksanaan IMD dengan kejadian stunting. Hal tersebut dapat terjadi karena banyak faktor lain yang dapat memengaruhi kejadian stunting 9

Stunting pada balita di Indonesia tidak disebabkan oleh 1 penyebab pada 1 masa tahap pertumbuhan saja, namun proses tersebut di sebabkan oleh multifactor dan berkesinambungan, dimulai dari saat konsepsi hingga balita berusia 2 tahun. Pada periode tersebut banyak permasalahan kesehatan yang dapat terjadi khususnya mengenai praktik pengasuhan yang kurang optimal, diantaranya anemia dan KEK pada saat hamil, ANC tidak sesuai standar, persalinan tidak ditolong oleh tenaga kesehatan, tidak melakukan IMD, tidak memberikan ASI ekslusif,tidak memberikan imunisasi dasar lengkap hingga tidak memberikan MP ASI yang baik. Semua siklus permasalahan tersebut terjadi pada 1000 HPK anak. Sehingga ibu sebagai orang terdekat yang memberikan pengasuhan pada balita, harus mendapatkan informasi yang memadai tentang optimalisasi pertumbuhan anak pada 1000 HPK sehingga dapat memaksimalkan perannya dan kasus malnutrisi pada balita dapat dicegah $^{2}$

Hasil analisis regresi logistic pada TABEL 3, menunjukkan bahwa BBLR, MPASI, 1000 HPK secara parsial memengaruhi terjadinya stunting dengan kekuatan hubungan OR $\left(\operatorname{Exp}^{\beta}\right)=$ yang paling besar adalah HPK= 37.347 dan paling kecil adalah $\mathrm{BBLR}=0.000$.

Model persamaan dari analisis ini adalah :

Logg odds $($ Stunting $)=23.948+22.207($ BBLR $)+5.240($ MPASI $)+3.620(1000 \mathrm{HPK})$.

1. Untuk variabal BBLR memiliki peluang terjadinya stunting sebesar 22,207 kali kejadian.

2. Untuk variabel MPASI memiliki peluang terjadinya stunting sebesar 5.240 kali kejadian

3. Untuk variabel 1000 HPK memiliki peluang terjadinya stunting sebesar 3,620 kali kejadian.

Dari hasil analisis model persamaan menunjukkan bahwa peluang terjadinya stunting lebih besar pada BBLR dengan nilai probabilitas sebesar 22.207 


\section{SIMPULAN}

Variabel yang berhubungan adalah BBLR, Ibu hamil yang menderita KEK, asi eksklusif, MP ASI, informasi 1000 HPK. Sementara BBLR, MPAsi, 1000 HPK secara parsial memengaruhi terjadinya stunting dan yang memiliki peluang besar untuk memengaruhi kejadaian stunting adalah BBLR

\section{SARAN}

Peneliti menyarankan untuk penelitian selanjutnya untuk memperbanyak sampel dan membahas lebih banyak tentang asupan gizi saat pemberian MP ASI serta meneliti model pencegahan stunting dengan variabel yang telah ditemukan.

\section{UCAPAN TERIMA KASIH}

Terima kasih Penulis sampaikan kepada Poltekkes Kemenkes Pontianak yang telah membiayai dan memfasilitasi peneltian ini hingga selesai.

\section{DAFTAR PUSTAKA}

1. Kementerian Kesehatan Republik Indonesia. (2018). Riset Kesehatan dasar Tahun 2018. https://doi.org/10.1177/109019817400200403

2. Kementerian Desa Pembangunan Daerah Tertinggal dan Transmigrasi. (2018). Buku saku desa dalam penanganan stunting. 2-13.

3. Tim Nasional Percepatan Penanggulangan Kemiskinan. (2017). 100 Kabupaten/Kota Prioritas untuk intervensi Anak Kerdil (Stunting).

4. Dinas Kesehatan Provinsi Kalimantan barat. (2019). Profil Kesehatan Provinsi Kalimantan Barat tahun 2018.

5. Puskesmas Saigon. (2019). Data Sekunder.

6. Nshimyiryo, A., Hedt-gauthier, B., Mutaganzwa, C., Kirk, C. M., Beck, K., Ndayisaba, A., ... El-khatib, Z. (2019). Risk factors for stunting among children under five years : a cross-sectional population-based study in Rwanda using the 2015 Demographic and Health Survey. 1-10.

7. Wiji, R. N. (2013). ASI dan Panduan Menyusui. Yogyakarta.

8. Maryunani, A. (2015). Inisiasi Menyusu Dini, Asi Eksklusif dan Manajemen Laktasi. Jakarta.

9. Paudel, R., Pradhan, B., \& Pahari, D. P. (2012). Risk Factors for Stunting Among Children : A Community Based Case Control Risk Factors for Stunting Among Children : A Community Based Case Control Study in Nepal. Kathmandu University Medical Journal, (July). https://doi.org/10.3126/kumj.v10i3.8012

10. Hairunis, M. N., Rohmawati, N., \& Ratnawati, L. (2016). Determinan Kejadian Stunting Pada Anak Balita Di Wilayah Kerja Puskesmas Soromandi Kabupaten Bima Nusa Tenggara Barat. E-Jurnal Pustaka Kesehatan, 4(2)(2), 323-329.

11. Ikatan Dokter Anak. (2017). Pemberian Makanan Pendamping Air Susu Ibu (MP ASI).

12. Qulub, S. T. (2016). 1000 Hari Pertama Kehidupan Perspektif Hukum Islam. 2 